\title{
A giant? Think of genetics: growth hormone-producing adenomas in the young are almost always the result of genetic defects
}

\author{
Constantine A. Stratakis ${ }^{1}$
}

Received: 21 April 2015/ Accepted: 26 May 2015/Published online: 9 June 2015

(C) Springer Science+Business Media New York (outside the USA) 2015

Giants (from the Greek " $\Gamma^{\prime} \gamma \alpha \nu \tau \varepsilon \varsigma$ ") are known from ancient times in all societies and cultures (Fig. 1). In Greek mythology, the giants challenged the Olympian Gods for supremacy in the world in a battle known as gigantomachy. In Hebrew, the nephilim were giants that existed before the flooding that occurred at Noah's time; Goliath was a giant Philistine warrior who was defeated by David, the man who was to become king of Israel. Both gigantes and nephilim were related to the divine but seen as different, even vile; they had to be eliminated: in fact, one of the reasons for Noah's flooding was to get rid of the nephilim. To this day, Enceladus ('E $\gamma \kappa \varepsilon \bar{\varepsilon} \lambda \alpha \delta \circ \varsigma$ ), a giant who was buried under Aetna, is one of the Greek words for earthquake. Thus, humans of large size were always around: the Irish giants were famous in the 1700s; the Alton giant (Robert Pershing Wadlow, 1918-1940) was the tallest man of his time and of international fame, just like today every move of a 2.51-m-tall Turkish man makes world news.

Although unusually large size in humans always existed, it was most likely the result of de novo mutations that were apparently never selected for, at least not in Homo Sapiens. Not favoring the large size as a trait was seen by the old texts as nemesis to the hubris of oversize and was most likely the result of disease conferred by the excess growth hormone $(\mathrm{GH})$ but also perhaps due to other coexisting morbidities in the context of genetic, syndromic

Constantine A. Stratakis

stratakc@mail.nih.gov

1 Program on Developmental Endocrinology \& Genetics (PDEGEN), Section on Endocrinology \& Genetics (SEGEN), Eunice Kennedy Shriver National Institute of Child Health \& Human Development (NICHD), NIH, CRC - Rm 1-3330, East Laboratories, Building 10-CRC, 10 Center Drive, Bethesda, MD 20892, USA associations. Nevertheless, the existence of multiple affected members of a clan or family (there were many Giants and Nephilim, and Goliath had both a large brother and three giant sons) [1] pointed to not only de novo defects but also some that could be inherited, at least for some generations.

The evidence for occasional inheritance aside, why was gigantism not favored as a trait? Not only the size of the known affected families was small but the life span of sporadic giants was also short (Mr. Wadlow died at the age of 22 years). Today, we know that at least part of the answer to this question is that almost every gene involved in the genetics of predisposition to gigantism or acromegaly or in somatic mutations in GH-producing pituitary adenomas (GHPAs) is a potent oncogene or tumor suppressor gene that is regulating a major signaling pathway [2].

GNAS defects (activating mutations of the G-protein stimulatory subunit alpha, Gs $\alpha$ ) are not even compatible with life in the germline; somatic GNAS defects lead to gigantism in McCune-Albright syndrome (MAS) and in acromegaly when confined to sporadic GHPAs [3]. PRKARIA mutations that lead to increased cAMP signaling, just like GNAS mutations, are responsible for gigantism or acromegaly in the context of Carney complex (CNC) but have never been found in sporadic GHPAs [4]. MEN1 (menin) gene mutations lead to gigantism and/or acromegaly in the context of multiple endocrine neoplasia (MEN) type 1 (MEN 1) but only rarely in sporadic acromegaly [5]. Mutations in the cyclin-dependent kinase $(\mathrm{CDKN}) 1 \mathrm{~B}(C D K N 1 B)$ are found in MEN type 4 (MEN 4) [6]; other CDKNs, all essential molecules in the regulation of cell cycle, growth, and proliferation, are mutated, rarely, in MEN 1/MEN 4-like syndromic gigantism and/or acromegaly but not in sporadic GHPAs [7]. Most of the patients with gigantism before puberty have defects on the 

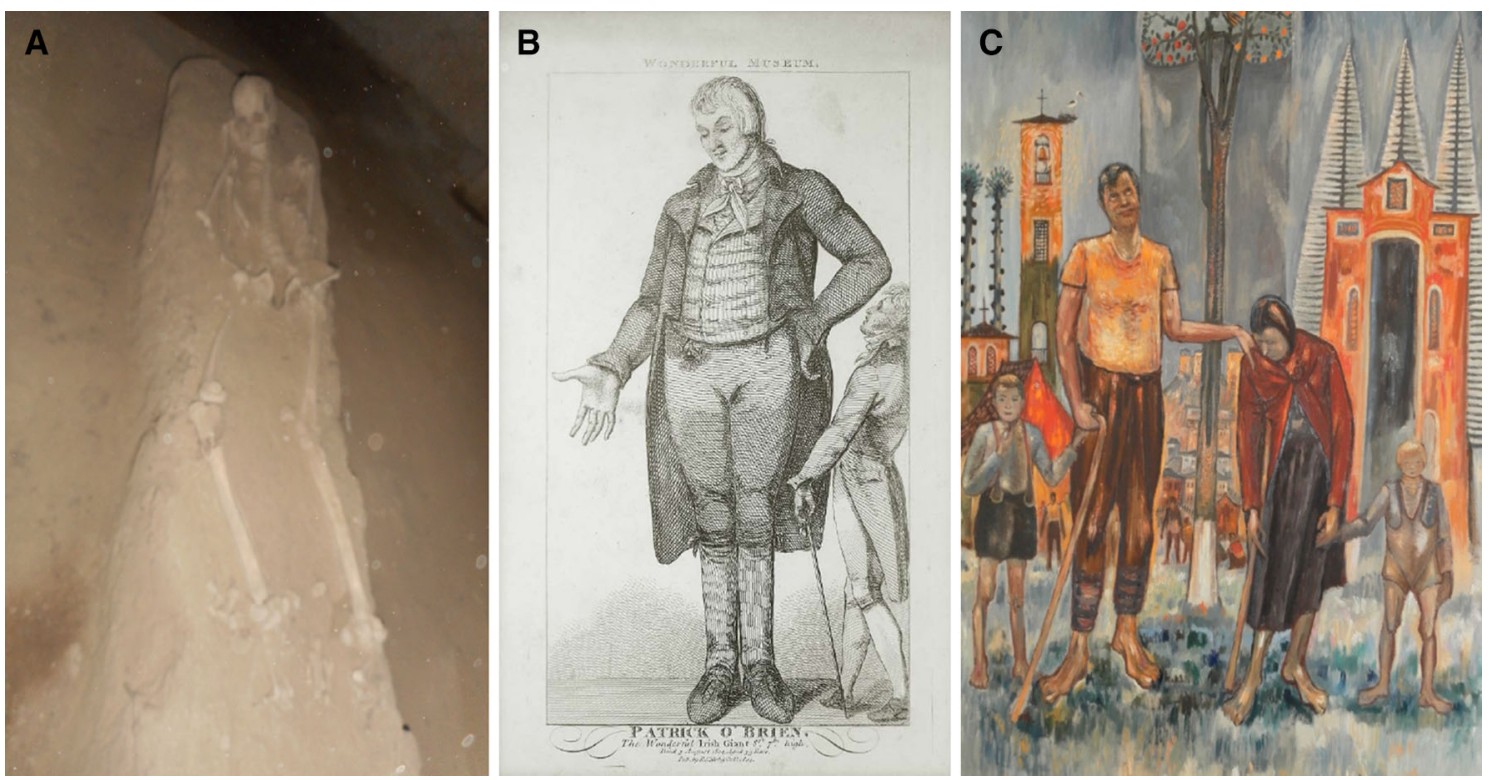

Fig. 1 a A giant woman (height more than $2 \mathrm{~m}$ ) buried in the cemetery of Viminacium (VIMINACIUM), the capital of the Roman province of Moesia Superior (today's Serbia) near the villages of Stari Kostolac and Drmno, about $12 \mathrm{~km}$ from the town of Kostolac, southeast of Belgrade. b Patrick O'Brien, one of the Irish giants (courtesy of Dr. Alan Guttmacher, Bethesda, MD, USA). c A painting from an unknown artist in Plovdiv (Пловдив), the former Philippopolis, in Bulgaria, showing a local giant
$\mathrm{X}$ chromosome in the context of a condition that is named $\mathrm{X}$-linked acrogigantism or X-LAG [8]; their presentation is rather dramatic and does not mimic the usually insidious onset of sporadic acromegaly [9]. Patients with familial isolated GHPAs (FIPA) also exist and may present with only gigantism or acromegaly; their genetic defect is in the aryl-hydrocarbon receptor-interacting protein or AIP [10]. AIP, although not known as a potent tumor suppressor or oncogene, is involved in many pathways, expressed in almost all cell types, and when inactivated appears to lead to aggressive GHPAs and/or hyperplasia, so much so that pediatric patients with AIP mutations can present with pituitary tumor apoplexy and panhypopituitarism $[10,11]$. Finally, syndromic gigantism or acromegaly can occur in the context of succinate dehydrogenase (SDH) mutations, where it is found in association with paragangliomas and pheochromocytomas [12] and/or other states, associated with multiple tumors and caused by yet unknown genetic defects [13].

In this issue of the journal, Sambugaro and Di Ruvo et al. [14] describe an unusual defect in one of the genes we mentioned above, the MEN 4 gene $C D K N 1 B$. A deletion in the $5^{\prime}$-UTR region (c.-29_-26delAGAG) was found in a patient who presented with gigantism due to GHPA during childhood. The defect led to a reduction in $C D K N 1 B$ mRNA levels, altered secondary mRNA structure, and reduced transcriptional activity of the gene in laboratory studies [14]. The report by Sambugaro and Di Ruvo et al. follows the identification of another 4-bp deletion
(c.-456_-453delCCTT) in a highly conserved regulatory region of the $5^{\prime} \mathrm{UTR}$ of the $C D K N 1 B$ gene in a patient with a pituitary adenoma and a well-differentiated pancreatic neoplasm [15].

The finding by Sambugaro and Di Ruvo et al. is significant for a number of reasons. First, although most cases of gigantism and early acromegaly after the recent identification of X-LAG $[8,9]$ have now been molecularly elucidated, there are several cases that have no identifiable genetic defects by current methods. These include not only syndromic cases [13] but also sporadic gigantism and certainly isolated GHPAs. Sequencing of the $5^{\prime}$-UTR region of genes that are involved in the molecular pathogenesis of GHPAs is not routinely done, and maybe we should consider this type of investigation in patients with gigantism or early acromegaly, positive family history, and/or other tumors that are negative for any of the known genetic defects. Second, transcription factors, microRNAs, and other molecules that may bind to regulatory elements in the $5^{\prime}$-UTR region of $C D K N 1 B$ or the other genes (GNAS, PRKARIA, MEN1, $A I P$, and other CDKNs) are de facto candidates for defects that may be causative of acromegaly. Third, in laboratory investigations of patients with GHPAs and negative for mutations in known genes, whole genome studies from sequencing to comparative genomic hybridization (CGH) may be at least as useful as whole exome sequencing (WES). CGH was essential in identifying the $\mathrm{X}$ chromosome defects in X-LAG, whereas WES was unsuccessful in identifying the causative gene [16]. 
And there is a fourth reason, entirely clinical, that the $C D K N 1 B$ gene promoter findings are significant: germline $C D K N 1 B$ defects are responsible for MEN4 and other endocrine tumors $[6,7]$ and somatic mutations are found frequently in sporadic small intestine neuroendocrine tumors (SI NETs) [17] among other neoplasms. Do the findings by Sambugaro and Di Ruvo et al. mean that patients with $C D K N 1 B$ promoter defects are at risk for additional neoplasms? Although we do not know the answer to this question, it is safe to recommend at least clinical (if not radiological) surveillance of patients carrying $C D K N 1 B$ promoter defects.

In conclusion, genetics has unraveled the mysteries of gigantism in just the last 10 years: who would have thought two decades ago that, by 2015, most children with gigantism would have an identifiable genetic cause? Although molecularly unexplained cases remain, they account for a relatively small percentage of GH excess in pediatrics and young adults. Thus, clinical endocrinology is now confronted with genetics and counseling, and lots of unknowns - a fitting, complicated state of affairs for the legendary gigantes and nephilim: a revenge of sorts? On the other hand, these findings augur well for new, molecularly designed treatments that will cure $\mathrm{GH}$ excess; gigantes and nephilim would have been thankful!

Acknowledgments This work was supported by the Intramural Research Program of the Eunice Kennedy Shriver National Institute of Child Health \& Human Development (NICHD), Bethesda, MD, USA (Grant: Z01 HD008920-04 to Dr. Stratakis).

Conflict of interests Dr. Stratakis is an employee of the US government and has no conflicts of interests to declare.

\section{References}

1. D.E. Donnelly, P.J. Morrison, Hereditary gigantism - the biblical giant Goliath and his brothers. Ulster Med. J. 83(2), 86-88 (2014)

2. P. Xekouki, M. Azevedo, C.A. Stratakis, Anterior pituitary adenomas: inherited syndromes, novel genes and molecular pathways. Expert Rev. Endocrinol. Metab. 5(5), 697-709 (2010)

3. P. Salpea, C.A. Stratakis, Carney complex and McCune Albright syndrome: an overview of clinical manifestations and human molecular genetics. Mol. Cell. Endocrinol. 386(1-2), 85-91 (2014)

4. A. Horvath, C.A. Stratakis, Clinical and molecular genetics of acromegaly: MEN1, Carney complex, McCune-Albright syndrome, familial acromegaly and genetic defects in sporadic tumors. Rev. Endocr. Metab. Disord. 9(1), 1-11 (2008)

5. C.A. Stratakis, M.A. Tichomirowa, S. Boikos, M.F. Azevedo, M. Lodish, M. Martari, S. Verma, A.F. Daly, M. Raygada, M.F. Keil, J. Papademetriou, L. Drori-Herishanu, A. Horvath, K.M. Tsang, M. Nesterova, S. Franklin, J.F. Vanbellinghen, V. Bours, R. Salvatori, A. Beckers, The role of germline AIP, MEN1, PRKAR1A, CDKN1B and CDKN2C mutations in causing pituitary adenomas in a large cohort of children, adolescents, and patients with genetic syndromes. Clin. Genet. 78(5), 457-463 (2010)
6. I. Marinoni, N.S. Pellegata, p27kip1: a new multiple endocrine neoplasia gene? Neuroendocrinology 93(1), 19-28 (2011)

7. S.K. Agarwal, C.M. Mateo, S.J. Marx, Rare germline mutations in cyclin-dependent kinase inhibitor genes in multiple endocrine neoplasia type 1 and related states. J. Clin. Endocrinol. Metab. 94(5), 1826-1834 (2009)

8. G. Trivellin, A.F. Daly, F.R. Faucz, B. Yuan, L. Rostomyan, D.O. Larco, M.H. Schernthaner-Reiter, E. Szarek, L.F. Leal, J.H. Caberg, E. Castermans, C. Villa, A. Dimopoulos, P. Chittiboina, P. Xekouki, N. Shah, D. Metzger, P.A. Lysy, E. Ferrante, N. Strebkova, N. Mazerkina, M.C. Zatelli, M. Lodish, A. Horvath, R.B. de Alexandre, A.D. Manning, I. Levy, M.F. Keil, L. Sierra Mde, L. Palmeira, W. Coppieters, M. Georges, L.A. Naves, M. Jamar, V. Bours, T.J. Wu, C.S. Choong, J. Bertherat, P. Chanson, P. Kamenický, W.E. Farrell, A. Barlier, M. Quezado, I. Bjelobaba, S.S. Stojilkovic, J. Wess, S. Costanzi, P. Liu, J.R. Lupski, A. Beckers, C.A. Stratakis, Gigantism and acromegaly due to Xq26 microduplications and GPR101 mutation. N. Engl. J. Med. 371(25), 2363-2374 (2014)

9. A. Beckers, M. Lodish, G. Trivellin, L. Rostomyan, M. Lee, F.R. Faucz, B. Yuan, C. Choong, J.H. Caberg, E. Verrua, L.A. Naves, T. Cheetham, J. Young, P. Lysy, P. Petrossians, A. Cotterill, N. Shah, D. Metzger, E. Castermans, M.R. Ambrosio, C. Villa, N. Strebkova, N. Mazerkina, S. Gaillard, G. Barcelos Barra, L.A. Casulari, S. Neggers, R. Salvatori, M.L. Jaffrain-Rea, M. Zacharin, B. Lecumberri Santamaria, S. Zacharieva, E.M. Lim, G. Mantovani, M.C. Zatelli, M.T. Collins, J.F. Bonneville, M. Quezado, P. Chittiboina, E. Oldfield, V. Bours, P. Liu, W.W. de Herder, N.S. Pellegata, J.R. Lupski, A.F. Daly, C.A. Stratakis, $\mathrm{X}$-linked acrogigantism (X-LAG) syndrome: clinical profile and therapeutic responses. Endocr. Relat. Cancer 22(3), 353-367 (2015)

10. A.F. Daly, A. Beckers, Familial isolated pituitary adenomas (FIPA) and mutations in the aryl hydrocarbon receptor interacting protein (AIP) gene. Endocrinol. Metab. Clin. North Am. 44(1), 19-25 (2015)

11. P. Xekouki, S.A. Mastroyiannis, D. Avgeropoulos, M. de la Luz Sierra, G. Trivellin, E.A. Gourgari, C. Lyssikatos, M. Quezado, N. Patronas, C. Kanaka-Gantenbein, G.P. Chrousos, C.A. Stratakis, Familial pituitary apoplexy as the only presentation of a novel AIP mutation. Endocr. Relat. Cancer 20(5), L11-L14 (2013)

12. P. Xekouki, E. Szarek, P. Bullova, A. Giubellino, M. Quezado, S.A. Mastroyannis, P. Mastorakos, C.A. Wassif, M. Raygada, N. Rentia, L. Dye, A. Cougnoux, D. Koziol, M. de La Luz Sierra, C. Lyssikatos, E. Belyavskaya, C. Malchoff, J. Moline, C. Eng, Maher L.J. Third, K. Pacak, M. Lodish, C.A. Stratakis, Pituitary adenoma with paraganglioma/pheochromocytoma (3PAs) and succinate dehydrogenase defects in human and mice. J. Clin. Endocrinol. Metab. 100(5), E10-E19 (2015)

13. P.L. Mai, L. Korde, J. Kramer, J. Peters, C.M. Mueller, S. Pfeiffer, C.A. Stratakis, P.A. Pinto, G. Bratslavsky, M. Merino, P. Choyke, W.M. Linehan, M.H. Greene, A possible new syndrome with growth-hormone secreting pituitary adenoma, colonic polyposis, lipomatosis, lentigines and renal carcinoma in association with familial testicular germ cell malignancy: a case report. J. Med. Case Rep. 1, 9 (2007)

14. S. Sambugaro, M. Di Ruvo, M.R. Ambrosio, N.S. Pellegata, M. Bellio, A. Guerra, M. Buratto, M.P. Foschini, F. Tagliati, E.D. Uberti, M. Chiara Zatelli, Early onset acromegaly associated with a novel deletion in $C D K N 1 B 5^{\prime} \mathrm{UTR}$ region. Endocrine 49, 58 (2015)

15. G. Occhi, D. Regazzo, G. Trivellin, F. Boaretto, D. Ciato, S. Bobisse, S. Ferasin, F. Cetani, E. Pardi, M. Korbonits, N.S. Pellegata, V. Sidarovich, A. Quattrone, G. Opocher, F. Mantero, C. Scaroni, A novel mutation in the upstream open reading frame 
of the $C D K N 1 B$ gene causes a MEN4 phenotype. PLoS Genet. 9(3), e1003350 (2013)

16. F.R. Faucz, A.D. Horvath, M.F. Azevedo, I. Levy, B. Bak, Y. Wang, P. Xekouki, E. Szarek, E. Gourgari, A.D. Manning, R.B. de Alexandre, E. Saloustros, G. Trivellin, M. Lodish, P. Hofman, Y.C. Anderson, I. Holdaway, E. Oldfield, P. Chittiboina, M. Nesterova, N.R. Biermasz, J.M. Wit, D.J. Bernard, C.A. Stratakis, Is $I G S F 1$ involved in human pituitary tumor formation? Endocr. Relat. Cancer 22(1), 47-54 (2015)

17. J.M. Francis, A. Kiezun, A.H. Ramos, S. Serra, C.S. Pedamallu, Z.R. Qian, M.S. Banck, R. Kanwar, A.A. Kulkarni, A. Karpathakis, V. Manzo, T. Contractor, J. Philips, E. Nickerson, N.
Pho, S.M. Hooshmand, L.K. Brais, M.S. Lawrence, T. Pugh, A. McKenna, A. Sivachenko, K. Cibulskis, S.L. Carter, A.I. Ojesina, S. Freeman, R.T. Jones, D. Voet, G. Saksena, D. Auclair, R. Onofrio, E. Shefler, C. Sougnez, J. Grimsby, L. Green, N. Lennon, T. Meyer, M. Caplin, D.C. Chung, A.S. Beutler, S. Ogino, C. Thirlwell, R. Shivdasani, S.L. Asa, C.R. Harris, G. Getz, M. Kulke, M. Meyerson, Somatic mutation of CDKN1B in small intestine neuroendocrine tumors. Nat. Genet. 45(12), 1483-1486 (2013) 